\title{
INFORMATION SOURCES IN LEGAL RESEARCH
}

\section{MARK VALE, PH.D.}

In 1990. the Alhertu Legal Informution Technolog. Assessiment Project' se'mt a survey to all lawyers om the Lau Sociely of Alberta 's mailing list. We asked them io tell us about their usc of informatiom sources and information technolagy in their practices. Over 20\% of the profession resyomded in our survey: an excellent response rate. The survey insirmment was basced on thut used by Profession Vale in his 1987 study of Onuario lan?ers, which he very kindly shered with us. The following is Professor Vale's summern of our date."
En 1990, dewrs te cadre d'im projes d'eivaluation de la rectmologice de docume'ntation juridiqus'. mons avons entove un questionmuire à rous les anocats figuram sur la liste de distribution de la law Socict!y. of Alherta. Nonss leur àosns demandé de décrire comment ils urilisent les sources d'informotion ef la sechnologice infermatique dans leurs pratiques. Plas

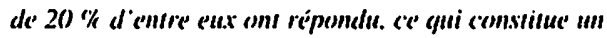

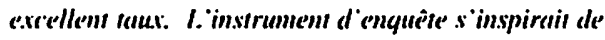

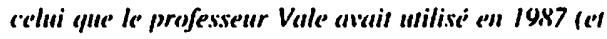
qu'il moss a gracicuscment communiqué) doms léfude qu'il avail consacrée aux avocuts ontariens. Le profisseier Vale pressente ici le sommenire de mos dominces.

\section{TABLE OF CONTENTS}

I. GENERAL RESEARCH PATTERNS $\ldots \ldots \ldots \ldots \ldots \ldots \ldots . \ldots \ldots 35$

II. PURPOSE OF RESEARCH $\ldots \ldots \ldots \ldots \ldots \ldots \ldots \ldots \ldots \ldots .335$

III. RESOURCES FOR RESEARCH $\ldots \ldots \ldots \ldots \ldots \ldots \ldots \ldots 336$

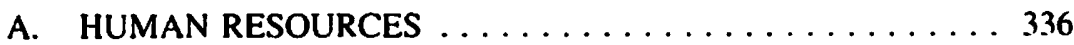

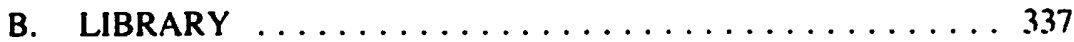

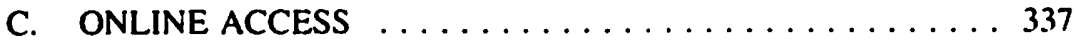

D. USE OF OTHER ELECTRONIC

INFORMATION TECHNOLOGY $\ldots \ldots \ldots \ldots \ldots \ldots \ldots .3 .38$

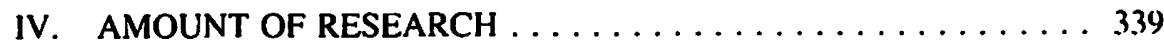

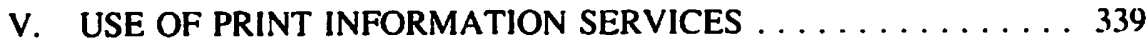

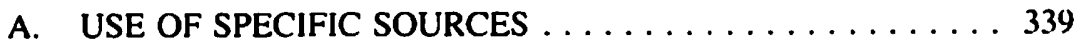

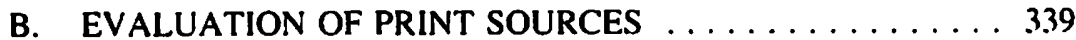

VI. USE OF ONLINE INFORMATION SERVICES $\ldots \ldots \ldots \ldots \ldots 342$

A. FREQUENCY OF ONLINE USE $\ldots \ldots \ldots \ldots \ldots \ldots \ldots 342$

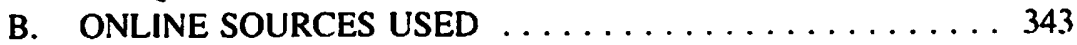

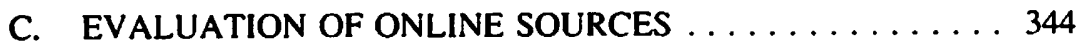

D. EFFECT OF ONLINE USAGE ON

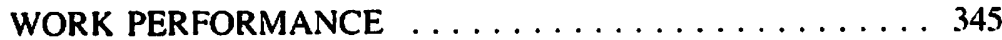

E. WHY MORE LAWYERS ARE NOT USING

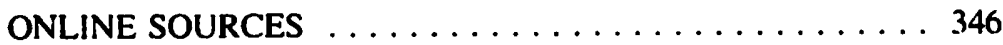

VII. INTEREST IN NEW LEGAL TECHNOLOGIES

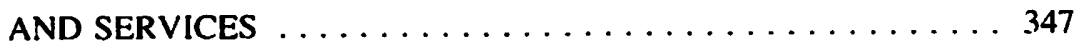

VIII. CONCLUSION $\ldots \ldots \ldots \ldots \ldots \ldots \ldots \ldots \ldots \ldots \ldots \ldots \ldots \ldots$

President, Information Management and Economics. Inc: Adjunct Prolessor of Communications, York University, Toronto.

ALITA is funded by the Alberta Law Foundation and sponsored by the University of Altherta Faculty of Law and the Alberta Law Reform Institute. Its Director is Professor Robert Franson.

$2 \quad$ Kate Welsh. Director of Rescarch. ALITA. 


\section{GENERAL RESEARCH PATTERNS}

Lawyers in Alberta reported spending about the same amount of time doing legal research in 1990) as in 1972. Operation Compulex ${ }^{3}$ reported that lawyers spent approximately $10 \%$ of their time performing legal research. In the current study, Alberta lawyers reported spending $12 \%$ of their work time, on average, doing legal research.

In the following sections, survey results are presented covering general patterns of research among lawyers. The purpose of research, resources available to support research, the amount of research and use of specific print and online sources of information are covered. As well. lawyers' evaluations of legal information sources they use are presented.

\section{PURPOSE OF RESEARCH}

Respondents were asked to rate the importance of specific reasons for doing research. Each reason was rated on a five-point scale from "almost never important" (1) as a reason for research to "almost always important" (5).

For most lawyers, rescarch is focused around problem-solving related to their work. Of all the reasons listed, the most important reason for doing research was to solve a particular problem (see Table 1). Considered above average in importance were to get the most timely information and to "keep up-to-date." Below average in importance for Alberta lawyers were gaining exhaustive access to a particular topic and to browse information sources. The least important reason was to get historical information.

Table 1

Reasons for Doing Legal Rescarch

$$
(\mathrm{N}=1107)
$$

\begin{tabular}{||clc||}
\hline $\begin{array}{c}\text { Rank } \\
\text { Order }\end{array}$ & \multicolumn{1}{c}{ Reason } & $\begin{array}{c}\text { Mean Score } \\
\text { (Scale of 1-5) }\end{array}$ \\
\hline \hline 1. & To solve a particular problem & 4.62 \\
\hline 2. & To get the most timely information & 4.00 \\
\hline 3. & To gain current awareness and to keep up-to-date & 3.30 \\
\hline 4. & To gain exhaustive access to a particular topic & 3.18 \\
\hline 5. & To get supplemental information & 3.00 \\
\hline 6. & $\begin{array}{l}\text { To browse information sources for new things I may } \\
\text { have missed or not thought of }\end{array}$ & 2.70 \\
\hline
\end{tabular}




\begin{tabular}{|ccc|}
\hline $\begin{array}{l}\text { Rank } \\
\text { Order }\end{array}$ & Reason & $\begin{array}{c}\text { Mean Score } \\
\text { (Scale of 1-5) }\end{array}$ \\
\hline 7. & To get historical information & 2.02 \\
\hline
\end{tabular}

\section{RESOURCES FOR RESEARCH}

Access is a necessary, but not sufficient, factor enabling individuals to use resource material. Respondents were asked whether they had access to (a) a library and (b) online databases at their place of work. Because proximity of sources has been shown to influence use, respondents were asked to indicate the proximity of these two research resources to their own office. The availability of human resources to assist in research work also was explored.

\section{A. HUMAN RESOURCES}

For the vast majority of lawyers, research remains an activity that the individual lawyer performs. Three out of every four respondents reported doing research themselves all of the time or frequently (Table 2 ), while only $6.2 \%$ reported that they seldom or never do research themselves.

In addition to performing research, a lawyer may also employ human resources to do research activities. Less than one percent of the lawyers in Alberta always had an assistant perform research functions. Almost another two in ten frequently employed an assistant to perform research. On the other hand, half of all the lawyers in the province seldom or never hired an assistant to perform research duties (Table 2).

Table 2

Human Resources for Legal Research ${ }^{4}$

$$
(\mathrm{N}=1107)
$$

\begin{tabular}{||l|cc||}
\hline & $\begin{array}{c}\text { Perform } \\
\text { Self } \\
\%\end{array}$ & $\begin{array}{c}\text { Others } \\
\text { Perform } \\
\%\end{array}$ \\
\hline \hline Always & 27.5 & .8 \\
\hline Frequently & 48.6 & 20.4 \\
\hline Sometimes & 17.8 & 26.0 \\
\hline Seldom & 5.7 & 29.8 \\
\hline Never & .5 & 22.9 \\
\hline
\end{tabular}

Percentages in this and other tables may not sum to $100.0 \%$ due to rounding. 


\section{B. LIBRARY}

A standard feature of a law office is its library. Because print is the traditional medium for legal information, almost all lawyers find it necessary to maintain a collection of law books in their office. About $89 \%$ of the lawyers in Alberta have access to a library in their place of work (Table 3). For $70 \%$ of the lawyers, the library is either in their own office or on the same floor.

When rating the quality of their library, $26 \%$ of the respondents rated their libraries as excellent. Another $60 \%$ said their libraries were "adequate" or "usually adequate." However, almost fifteen percent felt their libraries were inadequate.

\section{ONLINE ACCESS}

Unlike access to print sources, only $53.3 \%$ of the lawyers in Alberta had access to online databases at their law office in 1990 (Table 3). Most lawyers who did have access to online databases had to access them in another room. Only $5.7 \%$ had access to electronic information sources in their own office.

Tuble 3

Access to Library and Online Resources

$$
(\mathrm{N}=1044)
$$

\begin{tabular}{||l|cc||}
\hline & $\begin{array}{c}\text { Library } \\
\%\end{array}$ & $\begin{array}{c}\text { Online } \\
\%\end{array}$ \\
\hline No & 11.3 & 46.7 \\
\hline Yes & & 5.7 \\
\hline In personal office & 1.2 & 3.0 \\
\hline In secretary's office & 54.3 & 22.0 \\
\hline Another room, same floor & 17.6 & 14.5 \\
\hline Different floor, 1 above/1 below & 4.7 & 4.0 \\
\hline More than one floor away & 4.0 & 3.4 \\
\hline Not specified & & \\
\hline
\end{tabular}




\section{USE OF OTHER ELECTRONIC INFORMATION TECHNOLOGY}

In an effort to assess the diffusion of other electronic information technology in the law office and the resource environment in the law office, respondents were asked about the availability and use of computerized accounting, billing, calendar control, word processing. electronic in-house retrieval systems and electronic mail (Table 4).

By far, the technology with the greatest use in the law office environment was word processing equipment $(92.7 \%)$. Only six percent of lawyers in the province did not have access to this technology. Of the other technologies mentioned, only computerized accounting was used by more than half the lawyers in the province.

Table 4

Use of Information Technology

$$
(\mathrm{N}=1049)
$$

\begin{tabular}{||l|ccc||}
\hline \multicolumn{1}{|c|}{ Technology } & $\begin{array}{c}\text { Use } \\
\%\end{array}$ & $\begin{array}{c}\text { Do Not } \\
\text { Use } \\
\%\end{array}$ & $\begin{array}{c}\text { Not } \\
\text { Available } \\
\%\end{array}$ \\
\hline \hline Word Processing & 92.7 & 1.3 & 5.9 \\
\hline Computerized Accounting & 61.6 & 9.9 & 28.5 \\
\hline Automatic Document Preparation & 49.1 & 14.3 & 36.6 \\
\hline Computerized Billing & 47.7 & 16.8 & 35.5 \\
\hline Electronic In-house Retrieval System \\
(precedential material) & 40.8 & 14.5 & 44.7 \\
\hline Client Database & 34.8 & 19.3 & 45.9 \\
\hline Computer Litigation Support & 25.3 & 24.9 & 49.8 \\
\hline File Management & 25.0 & 14.3 & 36.6 \\
\hline Conflict of Intercst Determination & 23.9 & 22.1 & 54.1 \\
\hline Computer Limitations Diary & 23.9 & 25.3 & 50.8 \\
\hline Electronic Mail & 21.5 & 20.7 & 57.8 \\
\hline Computerized Calendar Control & 17.8 & 30.0 & 52.3 \\
\hline Personal Information Manager & 11.8 & 10.2 & 77.9 \\
\hline Electronic Conferencing & 11.6 & 25.9 & 62.5 \\
\hline
\end{tabular}




\section{AMOUNT OF RESEARCH}

Numerous questions in the survey focused on the amount and frequency of doing legal research. We purposely did not define the term "legal research." Thus, answers reflect the respondents" own perceptions of what constitutes legal research.

Almost half the lawyers in Alberta $(47 \%)$ said they did a 'moderate' amount of research. Just over ten percent of the lawyers said they did 'very little' or no research in their work, while another $19 \%$ considered they did a 'large amount' of legal research.

When asked specifically how many hours a week they spend doing legal research, the average was 5.2 hours per week. Ten percent of the sample reported spending less than one hour a week doing legal research, while almost twenty percent reported spending more than 10 hours per week in research activities.

Respondents were also asked to indicate what percentage of work time this research represented. On average. Alberta lawyers spent $12 \%$ of their work time doing research.

\section{USE OF PRINT INFORMATION SOURCES}

\section{A. USE OF SPECIFIC SOURCES}

Print information sources remain the dominant medium through which lawyers get information. Not surprisingly, eight of every ten lawyers in Alberta use print sources of information at least a few times every week.

The print information sources used by the greatest percentage of Alberta lawyers are legal textbooks, followed by Alberta Law Reports, Alberta Reports, Statutes of Canada, Dominion Law Reports, and the Statutes of Alberta. Table 5 presents typical print information sources used.

\section{B. EVALUATION OF PRINT SOURCES}

Alberta lawyers ratc the print sources available to them as "average" to ""good." On each of the fourteen attributes, the mean score was between 3 (average) and 4 (good) for the sample.

Relatively, the strongest characteristics of print sources are their usefulness, readability, and accessibility. Lawyers felt that the weakest characteristics of the print sources were the cost, their efficiency and their ease of use.

Table 6 presents lawyers' evaluation of print information sources they use in their practice of law. 
Table 5

Usc of Specific Print Information Sources

$$
(\mathrm{N}=1115)
$$

\begin{tabular}{|c|c|c|c|c|}
\hline & $\begin{array}{c}\text { Do Not } \\
\text { Use } \\
\%\end{array}$ & $\begin{array}{c}\text { Less Than } \\
1 \text { Hour } \\
\%\end{array}$ & $\begin{array}{c}1-3 \\
\text { Hours } \\
\%\end{array}$ & $\begin{array}{c}4 \text { or } \\
\text { More } \\
\text { Hours } \\
\%\end{array}$ \\
\hline Statutes of Canada & 30.2 & 60.5 & 6.5 & 2.7 \\
\hline Supreme Court Reports & 38.3 & 53.1 & 7.2 & 1.5 \\
\hline Statutes of Alberta & 37.2 & 43.4 & 37.1 & 12.3 \\
\hline Alberta Law Reports & 20.3 & 48.1 & 23.1 & 8.5 \\
\hline Alberta Reports & 25.6 & 47.4 & 20.0 & 7.1 \\
\hline Dominion Law Reports & 36.6 & 46.5 & 12.1 & 4.7 \\
\hline Western Weekly Reports & 22.0 & 52.0 & 18.7 & 6.3 \\
\hline Other Regional & 77.0 & 16.8 & 4.1 & 2.1 \\
\hline Business Law Reports & 72.6 & 24.5 & 2.2 & .7 \\
\hline Canadian Bankruptcy Report & 77.2 & 19.6 & 2.2 & 1.0 \\
\hline Canadian Criminal Cases & 73.1 & 15.3 & 7.1 & 4.5 \\
\hline Canadian Rights Report & 83.2 & 13.8 & 1.9 & 1.1 \\
\hline Criminal Reports & 78.5 & 14.2 & 4.8 & 2.6 \\
\hline Reports of Family Law & 74.6 & 18.6 & 5.0 & 1.8 \\
\hline Other Topical & 80.2 & 10.9 & 5.0 & 3.8 \\
\hline Alberta Decisions & 41.2 & 46.6 & 9.2 & 2.9 \\
\hline All Canada Weekly Summary & 60.8 & 33.8 & 4.0 & 1.4 \\
\hline Canadian Abridgement & 45.0 & 39.6 & 9.8 & 5.6 \\
\hline Canadian Current Law & 59.6 & 32.8 & 5.4 & 2.3 \\
\hline $\begin{array}{l}\text { Canadian Charter of Rights } \\
\text { Annotated }\end{array}$ & 82.2 & 15.1 & 2.0 & .7 \\
\hline Dominion Report Service & 80.6 & 17.2 & 1.4 & .8 \\
\hline LESA Research Guide & 77.2 & 19.1 & 2.4 & 1.3 \\
\hline
\end{tabular}




\begin{tabular}{|l|cccc||}
\hline & $\begin{array}{c}\text { Do Not } \\
\text { Use } \\
\%\end{array}$ & $\begin{array}{c}\text { Less Than } \\
\text { I Hour } \\
\%\end{array}$ & $\begin{array}{c}1-3 \\
\text { Hours } \\
\%\end{array}$ & $\begin{array}{c}\text { Mor } \\
\text { Hours } \\
\%\end{array}$ \\
\hline \hline English Law Reports & 68.3 & 28.6 & 2.2 & .9 \\
\hline U.S. Law Reports & 85.6 & 13.1 & .7 & .7 \\
\hline Legal Textbooks & 19.2 & 48.3 & 22.2 & 10.4 \\
\hline Law Journals & 46.5 & 43.3 & 7.4 & 2.7 \\
\hline Other Legal Information & 88.3 & 7.3 & 2.6 & 1.9 \\
\hline Other Non-legal & 35.8 & 42.3 & 13.9 & 8.0 \\
\hline
\end{tabular}

Table 6

Evaluation of Print Sources of Legal Information

$(\mathrm{N}=1115)$

\begin{tabular}{|c|c|c|c|c|c|}
\hline Rank & $\begin{array}{c}\text { Very } \\
\text { Poor } \\
\%\end{array}$ & $\begin{array}{l}\text { Poor } \\
\%\end{array}$ & $\begin{array}{c}\text { Average } \\
\%\end{array}$ & $\begin{array}{c}\text { Good } \\
\%\end{array}$ & $\begin{array}{c}\text { Excellent } \\
\%\end{array}$ \\
\hline 1. Useful & .1 & 1.0 & 22.2 & 61.6 & 15.1 \\
\hline 2. Accurate & 0.0 & 3.1 & 28.7 & 56.8 & 11.4 \\
\hline 3. Readable & .3 & 3.1 & 25.7 & 56.8 & 11.4 \\
\hline 4. Accessible & 1.1 & 6.1 & 23.5 & 54.1 & 15.1 \\
\hline 5. Reliable & .4 & 3.9 & 33.4 & 51.1 & 11.2 \\
\hline 6. Relevant & .5 & 4.8 & 36.4 & 49.9 & 8.5 \\
\hline 7. Detail & .1 & 6.2 & 36.3 & 47.7 & 9.7 \\
\hline 8. Amount of Information & .5 & 4.4 & 39.7 & 46.4 & 9.0 \\
\hline 9. Convenient & 1.6 & 11.4 & 36.7 & 41.1 & 9.3 \\
\hline 10. Organization & 1.6 & 9.7 & 40.5 & 40.2 & 8.0 \\
\hline 11. Timely & 1.4 & 10.8 & 39.8 & 41.2 & 6.8 \\
\hline $\begin{array}{l}\text { 12. Easy to Locate } \\
\text { Information }\end{array}$ & 1.9 & 15.2 & 44.9 & 32.8 & 5.2 \\
\hline 13. Efficient & 2.4 & 15.6 & 44.6 & 32.0 & 5.4 \\
\hline
\end{tabular}




\begin{tabular}{||l|ccccc|}
\hline \hline Rank & $\begin{array}{c}\text { Very } \\
\text { Poor } \\
\%\end{array}$ & $\begin{array}{c}\text { Poor } \\
\%\end{array}$ & $\begin{array}{c}\text { Average } \\
\%\end{array}$ & $\begin{array}{c}\text { Good } \\
\%\end{array}$ & $\begin{array}{c}\text { Excellent } \\
\%\end{array}$ \\
\hline 14. Cost & 5.8 & 16.5 & 45.3 & 25.1 & 7.3 \\
\hline
\end{tabular}

\section{USE OF ONLINE INFORMATION SOURCES}

One of the major purposes of the present study was to ascertain the extent to which lawyers were using online information sources in their legal research. In this section, the results of the survey for the use of online databases, the use of specific online information sources and an evaluation of online information sources are discussed. In addition, for those lawyers who did not use online information sources, the reasons for not using online databases were examined. Perhaps the must revealing result is that $52.9 \%$ thought they would never use online information sources. This figure may represent a ceiling for the potential adoption of online technology.

\section{A. FREQUENCY OF ONLINE USE}

While about half of the lawyers in Alberta had access to online databases in 1990, only $16 \%$ used these information sources at least once a week. When compared to use of print sources, online sources were used irregularly and infrequently for the vast majority of lawyers in the province.

Table 7 compares online use with print use among Alberta lawyers. While $43 \%$ of the lawyers in Alberta used print information sources every day, less than one percent of these lawyers used online databases every day. And while over $90 \%$ of Alberta lawyers used print information sources at least once a week, only $16 \%$ of Alberta lawyers used online information sources at least once a week. It is clear that print information sources remain the dominant medium through which Alberta lawyers seek legal information.

\section{Table 7}

Online Use Compared to Print Use

$$
(\mathrm{N}=1115)
$$

\begin{tabular}{||l|cc||}
\hline Frequency of Usc & $\begin{array}{c}\text { Print } \\
\%\end{array}$ & $\begin{array}{c}\text { On-line } \\
\%\end{array}$ \\
\hline Every day & 43.0 & 0.0 \\
\hline A few times a wcck & 37.8 & 9.4 \\
\hline Once a week & 11.1 & 6.8 \\
\hline Once or twice a month & 6.7 & 15.3 \\
\hline
\end{tabular}




\begin{tabular}{|l|cc||}
\hline Frequency of Use & $\begin{array}{c}\text { Print } \\
\%\end{array}$ & $\begin{array}{c}\text { On-line } \\
\%\end{array}$ \\
\hline \hline Less than once a month & 1.2 & 22.5 \\
\hline Never & .3 & 46.3 \\
\hline
\end{tabular}

\section{B. ONLINE SOURCES USED}

As with print sources, respondents were asked to indicate which specific sources of information they used when online. The online source most used by lawyers in Alberta was QL Systems and the databases on QL. Table 8 reports the use of online sources by respondents.

Tuble 8

Use of Specific Online Information Sources

(Users Only, $\mathrm{N}=554$ )

\begin{tabular}{|c|c|c|c|c|}
\hline & Do Not Use & $\begin{array}{l}\text { Less Than } 15 \\
\text { Mins }\end{array}$ & $\begin{array}{l}15-30 \\
\text { Mins }\end{array}$ & $\begin{array}{l}\text { 30) or Morc } \\
\text { Mins }\end{array}$ \\
\hline CAN/I.AW & 79.6 & 15.5 & .5 & 0.0 \\
\hline All Canada Weckly Summaries & 8.5 .9 & 12.8 & 1.3 & 0.0 \\
\hline Canadian Criminal Casts & 93.3 & 6.3 & 4 & 0.0 \\
\hline Can. Labxour Arhilration Summary & 95.1 & 4.3 & .5 & 0.0 \\
\hline Canadian Patent Reporter & 93.5 & 5.8 & .2 & .6 \\
\hline Dominion Law Reports & 77.3 & 58.8 & 2.9 & 1.1 \\
\hline Labour Artitration Cadses & 95.1 & 4.3 & .5 & 0.0 \\
\hline Weekly Criminal Bullelin & 93.1 & 5.8 & 1.1 & 0.0 \\
\hline Western Legual Publicalions & 87.7 & 10.8 & .9 & .6 \\
\hline CT Online & 9.3.0 & 4.3 & 2.0 & .8 \\
\hline DIALOG & 95.0 & 4.3 & .4 & 0.0 \\
\hline DYNIS & 98.4 & 1.4 & .2 & 0.0 \\
\hline FP Online & 96.6 & 2.9 & .5 & 0.0 \\
\hline INFO GLOBE & 94.6 & 4.5 & .9 & 0.0 \\
\hline
\end{tabular}




\begin{tabular}{|c|c|c|c|c|}
\hline & Do Not Use & $\begin{array}{c}\text { Less Than } 15 \\
\text { Mins }\end{array}$ & $\begin{array}{l}15-30 \\
\text { Mins }\end{array}$ & $\begin{array}{l}30 \text { or More } \\
\text { Mins }\end{array}$ \\
\hline News and Business Databases & 92.4 & 6.0 & 1.4 & .2 \\
\hline Index to Can. Legal Databases & 96.9 & 2.5 & .5 & 0.0 \\
\hline INSIGHT & 97.7 & 1.6 & .5 & .2 \\
\hline LEXIS & 94.4 & 5.1 & .4 & .2 \\
\hline NEXIS & 98.0 & 1.4 & .4 & .2 \\
\hline Ncws\$ource & 98.4 & 1.1 & .4 & .2 \\
\hline QL SYSTEMS & 52.5 & 26.7 & 10.3 & 10.5 \\
\hline Alberta Case Locator & 53.2 & 34.7 & 7.9 & 4.1 \\
\hline Can. Judgments & 52.3 & 3.3 .4 & 8.5 & 5.7 \\
\hline Dominion Reports Serv. & 58.5 & 31.0 & 6.1 & 4.3 \\
\hline Dominion Tax Casses & 87.5 & 9.9 & 1.3 & 1.3 \\
\hline Federal Coun Reports & 80.9 & 16.6 & 1.8 & .7 \\
\hline National Reporter & 54.9 & 31.0 & 8.7 & 5.4 \\
\hline Ontario Reports & 74.7 & 19.9 & 4.2 & 1.3 \\
\hline Statute and Regulations & 76.0 & 21.1 & 2.0 & .9 \\
\hline Western Wcckly Repons & 58.3 & 32.7 & 6.0 & 3.0 \\
\hline Vutext & 98.4 & 1.4 & .2 & 0.0 \\
\hline WESTLAW & 91.7 & 7.4 & .4 & .6 \\
\hline Other Online - Legal & 98.4 & .9 & .2 & .5 \\
\hline Other Online - Non-legal & 95.1 & 3.1 & .5 & 1.3 \\
\hline
\end{tabular}

\section{EVALUATION OF ONLINE SOURCES}

Among the fourteen attributes which respondents evaluated, online sources were rated the highest for their timeliness, usefulness and accuracy. Like print sources, online databases received their lowest rating for their cost and ease of use (Table 9). 
Table 9

Evaluation of Online Sources of Legal Information

$(\mathrm{N}=554)$

\begin{tabular}{|c|c|c|c|c|c|}
\hline Rank & $\begin{array}{c}\text { Very } \\
\text { Poor } \\
\%\end{array}$ & $\begin{array}{c}\text { Poor } \\
\%\end{array}$ & $\begin{array}{c}\text { Average } \\
\%\end{array}$ & $\begin{array}{c}\text { Good } \\
\%\end{array}$ & $\begin{array}{c}\text { Excellent } \\
\%\end{array}$ \\
\hline 1. Timely & .5 & 2.5 & 16.6 & 46.1 & 34.3 \\
\hline 2. Useful & .5 & 6.9 & 30.0 & 46.6 & 7.3 \\
\hline 3. Accessiblc & 1.4 & 14.9 & 29.3 & 39.1 & 15.3 \\
\hline 4. Accurate & 2.4 & 7.8 & 41.9 & 37.2 & 10.8 \\
\hline 5. Convenient & 2.1 & 16.0 & 33.3 & 34.5 & 85.9 \\
\hline 6. Efficient & 2.1 & 16.3 & 31.9 & 37.2 & 12.6 \\
\hline 7. Relevant Information & 3.5 & 12.9 & 37.9 & 34.6 & 11.1 \\
\hline 8. Amount of Information & 2.8 & 12.2 & 42.4 & 33.3 & 9.4 \\
\hline 9. Detuil & 1.6 & 14.3 & 43.1 & 30.9 & 10.1 \\
\hline 10. Reliable & 3.7 & 13.9 & 38.3 & 33.7 & 10.4 \\
\hline 11. Readable & 2.8 & 17.2 & 42.4 & 28.7 & 8.9 \\
\hline 12. Organization & 3.2 & 18.5 & 40.6 & 29.8 & 7.9 \\
\hline 13. Easy to Locatc Information & 7.4 & 24.8 & 38.2 & 22.7 & 6.9 \\
\hline 14. Cost & 13.1 & 26.9 & 35.7 & 18.8 & 5.5 \\
\hline
\end{tabular}

\section{EFFECT OF ONLINE USAGE ON WORK PERFORMANCE}

Lawyers who used online databases believed that the use of online databases increased their awareness of available information and decreased the amount of time it takes them to find information. A majority of these lawyers believed the use of online databases had no effect on the quantity of work done, their decision-making ability, or the quality of their work (Table 10). 
Table 10

Effects of Online Use on Work Performance

(Users Only, $\mathrm{N}=255$ )

\begin{tabular}{|c|c|c|c|c|c|}
\hline & $\begin{array}{c}\text { Significamly } \\
\text { Derniascd } \\
\%\end{array}$ & $\begin{array}{l}\text { IAxtcancd } \\
7\end{array}$ & $\begin{array}{c}\text { Noi biffert } \\
\text { ii }\end{array}$ & $\begin{array}{l}\text { Increasided } \\
*\end{array}$ & $\begin{array}{c}\text { Significuntly } \\
\text { Increased } \\
\text { a }\end{array}$ \\
\hline Quality of your work & 0.0 & 1.2 & 48.0 & 45.1 & 5.7 \\
\hline $\begin{array}{l}\text { Awarcness of available } \\
\text { information }\end{array}$ & 0.0 & 1.4 & 36.9 & 51.3 & 30.3 \\
\hline Decision-making ability & 0.2 & 1.4 & 63.6 & 31.5 & 3.3 \\
\hline Work confidence & 0.2 & 2.2 & 49.3 & 42.2 & 6.1 \\
\hline Quantity of work done & .4 & 3.7 & 69.3 & 23.2 & 3.5 \\
\hline Time laken to find informalion & 6.5 & 36.3 & 33.3 & 17.9 & 6.0 \\
\hline
\end{tabular}

\section{E. WHY MORE LAWYERS ARE NOT USING ONLINE SOURCES}

As discussed earlier, about half of the lawyers in Alberta had access to online databases in their place of work. This result, after more than ten years of availability, would lead one to believe that online databases are useful to only a limited number of lawyers. We asked respondents why they did not use online databases. The reasons most often cited are summarized in Table II.

Forty percent cited cost as the main reason for not using the medium. Lack of availability was the second-ranked reason for not using online sources.

\section{Table 11}

Reasons for Not Using Online Databases

$$
(\mathrm{N}=500 \text { ) }
$$

\begin{tabular}{|c|c|c|}
\hline Rank & Reason & Percent \\
\hline 1 & Not available & 40.3 \\
\hline 2 & Expensive, Cost. Not cost efficient & 39.6 \\
\hline 3 & No computer & 34.6 \\
\hline 4 & Dos not require & 18.0 \\
\hline 5 & Too hard to use & 17.0 \\
\hline 6 & No confidence in results & 15.2 \\
\hline
\end{tabular}




\begin{tabular}{|ccc|}
\hline Rank & Reuson & Percent \\
\hline 7 & Someone clse does unline research & 13.4 \\
\hline 8 & Not applicuble to practice & 10.4 \\
\hline 9 & Other & 16.8 \\
\hline
\end{tabular}

\section{INTEREST IN NEW LEGAL TECHNOLOGIES AND SERVICES}

Respondents were asked to rank seven types of technologies which could be introduced into the judicial system or lcgal practice. They were asked "for which do you see the greatest need?" The greatest interest was expressed toward an online statute database and electronic filing of judgments. The lowest interest was shown for a sentencing database.

Table 12

Preference for New Legal Technology/Services

$(N=1115$,

\begin{tabular}{|c|c|c|}
\hline Rank & ltem & $\begin{array}{c}\text { Mcan } \\
\text { (Scale of 1-5) }\end{array}$ \\
\hline I. & Online statute database & 3.277 \\
\hline 2. & Elcctronic liling of documents & 3.282 \\
\hline 3. & Elecironic distribution of judgments & 3.620 \\
\hline 4. & Online yuantum & 3.865 \\
\hline 5. & Computer-aided transcription of evidence & 4.053 \\
\hline 6. & Online trial scheduling and case tracking & 4.120 \\
\hline 7. & Sentencing dalabase & 4.977 \\
\hline
\end{tabular}

\section{CONCLUSION}

These results give us a description of the practice of legal research in 1990. They suggest that legal research remains a selected activity and is focused on solving specific problems. While most lawyers do a moderate amount of research, one in ten does very little or no research and about one in five does a lot of research. On average, lawyers in Alberta spend about five hours a week doing legal research.

Print information sources remain the dominant form of information used by lawyers and their quality is considered "average" to "good." 
Online databases are used primarily to update research done with traditional print media and are used regularly by only five percent of the lawyers in Alberta. Forty-six percent of the lawyers do not have access to online information technology.

In terms of other information technology in the law office, only word processing and computerized accounting are used by a majority of lawyers. Less than half the lawyers in the province use electronic in-house retrieval systems, electronic mail and computerized billing. 